\title{
АТЕЇЗМ В УКРАЇНСЬКІЙ РСР У ДРУГІЙ ПОЛОВИНІ 1960-Х - ПЕРШІЙ ПОЛОВИНІ 80-Х РОКАХ ХХ СТ.: ТЕОРІЯ, ПРОПАГАНДА, ПРОТИДІЯ (НА ПРИКЛАДІ ІВАНО-ФРАНКІВСЬКОЇ ОБЛАСТІ)
}

\begin{abstract}
Анотація. Формування атеїстичного світогляду серед населення Української РСР - одне з основних завдань місцевих державно-партійних органів влади у другій половині 1970-х pp. Проаналізовано особливості атеїстичної пропаганди у республіці на прикладі Івано-Франківської області у період розвинутого соціалізму. Розглянуто методи боротьби партчиновників із релігійністю населення, виокремлено спеџифіку діяльності обласних, районних Комісій сприяння дотриманню законодавства про релігійні культи, показано ефективність роботи атеїстичний бригад. Відзначено, що з метою посилення атеїстичної роботи, протидії «залишкам уніатства» партчиновники використовували лекції, розмови, тематичні вечори, демонстрації документальних фільмів, а також місцеву комуністичну пресу та радіо. Зауважено, що широко проводилася так звана «індивідуальна робота» з активними віруючими, під час якої розтлумачувалися базові принципи атеїзму, наголошувалося на неприпустимості порушення законодавства про релігійні культи.
\end{abstract}

Ключові слова: атеїзм, УРСР, КПУ, Івано-Франківська область, атеїстичні бригади, атеїстичний світогляд, атеїстична пропаганда.

Puyda Roman

Ivano-Frankivsk National Technical University of Oil and Gas

\section{ATHEISM IN THE UKRAINIAN SSR IN THE SECOND HALF OF THE 1960S - FIRST HALF OF THE 1980S: THEORY, PROPAGANDA, COUNTERFEIT (ON THE EXAMPLE OF IVANO-FRANKIVSK REGION)}

Summary. The formation of an atheistic worldview among the population of the Ukrainian SSR was one of the main tasks of local state and party authorities in the second half of the 1970s. Methods of struggle of party officials against religiosity of the population are considered, specificity of activity of regional, district Commissions of assistance to observance of the legislation on religious cults is allocated, efficiency of work of atheistic brigades, lecturers-agitators, local state-party authorities is shown. It was stated that the establishment of «Leninist principles in religious matters» in the Ivano-Frankivsk region met with resistance from the local population, especially in rural areas, where believers were significantly influenced by the underground Greek Catholic Church. It was noted that in order to strengthen atheistic work, counteract the "remnants of Uniatism", party officials used lectures, talks, themed evenings, screenings of documentaries, as well as the local communist press and radio. It was noted that the so-called «individual work» with active believers was widely carried out, during which the basic principles of atheism were explained, and the inadmissibility of violating the law on religious cults was emphasized. It has been proved that the state-party authorities of Ivano-Frankivsk region paid special attention to former Greek Catholic believers, so special thematic evenings were held in the villages where pro-Uniate believers lived in Tlumach and Dolyna districts of Ivano-Frankivsk region to promote atheism. Stankovtsi, Bubnyshche, Tanyava of Dolyna district in the 1970s special film lectures were held, where the films «Trojan Horse», "Vampires», "Last Pages» and others were shown. It is noted that due to the high religiosity of the population, the atheistic campaign of the state and party authorities in Ivano-Frankivsk region was quite chaotic, especially in rural areas, where Greek Catholic or Protestant believers were active.

Keywords: atheism, USSR, CPU, Ivano-Frankivsk region, atheistic brigades, atheistic worldview, atheistic propaganda.

$\Pi$ остановка проблеми. У другій половині 1960-х рр. в Українській РСР під впливом політичних фракторів розпочато масштабну кампанію атеїзації країни. Особливим розмахом вона проходила у західноукраїнських областях, де партчиновники 3 року в рік фіксували високий рівень релігійності населення. Показова у цьому відношенні Івано-Франківська область. У звітах місцевих державно-партійних органів влади із грифом «таємно» констатовано, що у другій половині 1968 року «партійні і радянські органи докорінно перебудували атеїстичну роботу по всіх ланках партійного, радянського, комсомольського, профрспілкового апаратів на підприемствах, установах, колгоспах... Змістовніше ведеться науково-атеїстична робота серед населення. До цього залучені великий колектив профресорсько-викладацького складу вищих і серед- ніх навчальних закладів, студенти старших курсів, старші комуністи» [1, арк. 148].

Аналіз останніх досліджень і публікацій. Державно-церковні відносини в УРСР уже не перший рік перебувають у полі зору українських істориків, релігієзнавців, фрілософрів, політологів, які упродовж останніх тридцяти років розкрили окремі аспекти проблеми. Узагальнюючі наукові студії учених загалом відображають загальну картину політики Центрального Комітету Комуністичної партії Радянського Союзу (ЦК КПРС) у релігійній сфрері, що зокрема помітно у дослідженнях О. Бажана, Ю. Данилюка [2], П. Бондарчука [3], В. Войналовича [4], В. Марчука [5], В. Пащенка [6] та ін., проте не у них не достатньо уваги приділено проблемі поширення атеїстичного світогляду у західноукраїнських областей. 
Мета статті - розглянути особливості атеїстичної кампанії державно-партійних органів влади в Івано-франківській області у період розвинутого соціалізму.

Виклад основного матеріалу дослідження. Атеїстична кампанія державно-партійних органів влади в Івано-Франківській області мала на меті, по-перше, знизити релігійну активність населення області i, по-друге, впровадити радянську обрядовість у побут мешканців краю. Перший фактор був визначальним, адже населення регіону зберігало релігійність, про що свідчать участь віруючих у релігійних святах. Зокрема, святкування Пасхи 10 квітня 1966 р. в ІваноФранківській області пройшло із значним розмахом, про що свідчать звіти уповноваженого Ради у справах релігій при Раді Міністрів СРСР. Члени комісії за дотриманням законодавства про релігійні культи сформованої Богородчанською районною радою (Івано-Франківська область), констатували: «Уже починаючи з 5-6 квітня в районі було помітно в деяких селах пожвавлення активності віруючих в підготовці до "пасхи», особливо в передпасхальні релігійні свята - четвер і п'ятницю. Дещо знижена трудова активність колгоспників в колгоспному виробництві, святкове вбрання віруючих, подекуди поява окремих осіб в нетверезому стані. В підготовці пасхального свята особливо позначилось на зниженні продажу населенням державі продуктів тваринництва - молока і яець» [7, арк. 226]. Пік святкування, закономірно, припав на неділю - в усіх 24 церквах проходило освячення пасок за участю «багатьох людей». Згідно з підрахунками членів комісії, у районі у церемонії освячення пасок взяли участь 75-80\% дворів сіл (з кожного двору церкву відвідало 1-2 особи). Особливо багато йшли до церкви у селах Росільня, Тисменичани, Лисець, Пороги, Яблунька, Горохоливо, Грабовець, Черніїв [7, арк. 226].

Тільки в Івано-Франківській області упродовж 1971-1976 рр. на обрядах хрещення, вінчання, похоронах були присутні понад 420 тис. осіб молодого і середнього віку. У 1975 р. було охрещено 42,6\% від загальної кількості новонароджених, вінчалося $12,6 \%$ від загального числа укладених шлюбів, відспівували в церкві на похоронах $64,8 \%$ осіб від загальної кількості померших. У першому кварталі 1976 р. виросла релігійна обрядовість в Долинському, Тлумацькому районах [8, арк. 126].

У 1982 р. в Івано-Франківській області й надалі зберігалася висока релігійність населення. В області функціонували 426 релігійних об'єднань, 3 яких 368 були зареєстрованими (355 громад РПЦ, 7 громад евангельських християн-баптистів, 5 громад адвентистів сьомого дня і 1 громада п'ятидесятників). Незареєстрованими залишалися 58 громад (42 - Свідків Сгови (1843 особи) і 16 - п’ятидесятників (868 осіб)). До цього варто додати релігійні громади греко-католиків [9, арк. 195]. У тому ж році із загальної кількості новонароджених 1340 осіб було охрещено 633 дитини (47 відсотків). У той же час вінчалися 108 пар (17\%), а похорони за участю священнослужителів відбулися у 88 відсотках випадків. Апарат місцевого уповноваженого Ради у справах релігій відзначав наявність фак- ту участі в обряді хрещення і вінчання членів ВЛКСМ [9, арк. 160].

Зважаючи на високу релігійність населення, атеїстична кампанія державно-партійних органів влади в Івано-Франківській області проходила доволі сумбурно, особливо у сільській місцевості. Івано-Франківський облвиконком повідомляв (1968 р.), що «робота, щодо встановлення ленінських принципів у релігійних питаннях, а також посилення ідейної боротьби з нею, сприяе послабленню її впливу на населення, особливо на молодь» [1, арк. 7]. Рада у справах релігій повідомляла, що «із звітів уповноважених видно, що найбільш слабким місцем роботи на місці є вивчення змісту релігійної пропаганди» (1967 р.). Більше того, окремі уповноважені «погано освідомлені із діяльністю релігійних організацій, не мають уявлення про склад духовенства, не звертають увагу місцевих органів влади на необхідність здійснення контролю за дотриманням законодавства про культи». Критика, зокрема, стосувалася уповноваженого по Хмельницькій (М. Котельніков) та Івано-Франківській (О. Атаманюк) областях [1, арк. 7].

План роботи уповноваженого Ради у справах релігій при Раді Міністрів СРСР в Івано-Франківській області (1969р.), зокрема, передбачав: провести за попередньої згодою із облвиконкомом заняття з головами сільських, селищних рад, партійним активом сіл області; виготовити необхідну кількість бланків для діяльності уповноваженого ради у справах релігій; провести інструктивний семінар із головами та секретарями райвиконкомів щодо особливостей діловодства по релігійним культам; виступити на зборах районних секретарів первинних парторганізацій з інформацією про необхідність посилення діяльності у сфері дотримання законодавства про релігійні культи; спільно з органами прокуратури перевірити правильність застосування Указу Президії Верховної Ради УРСР «Про адміністративну і кримінальну відповідальність осіб, як порушують законодавство про культи»; перевірити правильність застосування законодавства про культи місцевими органами влади та ін. [1, арк. 80].

Особливу роль в атеїстичній кампанії партчиновники приділяли святкуванню ювілейних дат. Так, для прикладу до 100-річчя від дня народження В. Ленінка обкоми Компартії України обладнювали «спеціальні будинки для урочистої реєстрації шлюбів і новонароджених». Водночас, чиновники були змушені констатувати, що «похорони все ще залишаються монополіею церкви і по лінії місцевих органів влади цьому питанню мало приділяеться уваги» [1, арк. 181]. Станом на 1974 р. в Івано-Франківській області було створено бл. 400 кімнат і будинків урочистих подій. У цей період 90-95\% шлюбів в Івано-Франківську, Снятівському, Косівському, Городнянському районах відбувалися відповідно до нових цивільних обрядів [8, арк. 128].

З метою посилення атеїстичної роботи, протидії «залишкам уніатства» партчиновники використовували лекції, розмови, тематичні вечори, демонстрації документальних фільмів, які розкривали «реакційну суть уніатства», таких як «Троянський кінь», «Вампіри», «Останні сторінки», а також пресу і радіо. Широко проводилася індивідуаль- 
на робота щодо роз'яснення уніатам радянського законодавства про культи, вони попереджуються про відповідальність за його порушення... Для боротьби з уніатами використовуються можливості православного духовенства...» [8, арк. 23].

Едективність роботи атеїстичний бригад, лекторів-агітаторів, місцевих радянсько-партійних органів влади залишалася вкрай низькою. Для прикладу, у селі Пороги (Івано-Франківська область) комісія за контролем щодо дотримання законодавства про культи (голова - В. Дроздик) відповідно до звітних документів «займалася постійною атеїстичної роботою». Про ефективність такої роботи красномовно свідчать фракти: у 1982 році із 69 новонароджених дітей, 67 були хрещені, а 328 зареєстрованих шлюбів, 21 подружня пара вінчалися у Церкві. У селі Марків (Івано-Франківська область) із 53 новонароджених, 29 - хрещені (54 відсотки), із 17 зареєстрованих шлюбів, 8 подружніх пар і вінчалися у Церкві села Манява. Із 19 померших у 1982 році тільки два члени КПРС М. Мундяк і М. Кріца були похоронені відповідно до радянської обрядовості, хоча й у цих випадках згодом на їх могилах обеліски були замінені на хрести [9, арк. 162].

У 1977 р. 3 ініціативи Уповноваженого Ради у справах релігій при раді Міністрів УРСР в Івано-Франківській області була створена обласна Комісія сприяння виконання законодавства про культи, яку очолила заступник голови облвиконкому О. Панюк. До її складу увійшли представники обкому Компартії України, обкому Комсомолу, обласного суду, Міністерства Внутрішніх Справ, Комітету Державної Безпеки. Комісія збиралася на свої засідання не рідше ніж два рази на тиждень i, де-фракто, стала виконувати роль координаційної ради [9, арк. 194].

Після розгляду того чи іншого питання, інформаційні справки і рекомендації комісї розсилалися до всіх райміськвиконкомів. Для прикладу, у 1979 р. обласною комісією був розроблений комплекс заходів (на прикладі Надвірнянського району) щодо недопущення і протидії проведення масових легальних зборів (під виглядом весіль, похоронів) незареестрованими релігійними громадами, зокрема п'ятидесятниками та свідками Єгови. У результаті таких заходів, на думку членів Ради у справах релігій при Раді Міністрів УРСР, в області була повністю призупинена діяльність протестантських громад. Іншою фрормою роботи комісії була підготовка матеріалів із оглядом релігійної панорами області. Щороку зусиллями Уповноваженого ради у справах релігій при раді Міністрів УРСР в Івано-Франківській області, а також обласною комісією проводилися семінари для голів комісій 3 виконання законодавства про культи райміськвиконкомів. Зокрема, у 1981 році було проведено 5 обласних семінарів. Крім того, у тому ж році організовано 16 кущових і 55 районних аналогічних семінарів [9, арк. 195].

Обласна комісія розробляла нормативно-правові документи, які, знову ж таки, розсталася до районів області. Зокрема у 1981-1982 рр. іванофрранківською обласною комісією були підготовлені: Пам'ятка про роботу сільських і селищних рад народних депутатів щодо контролю за дотриманням законодавства про релігійні культи;
Пам'ятка-інструкщія про роботу районних і міських рад народних депутатів щодо контролю за дотриманням законодавства про релігійні культи. Апаратом Уповноваженого ради у справах релігій при Раді Міністрів УРСР в Івано-Франківській області спільно з обласною комісією, відділом пропаганди й агітащії обкому Компартії України, відділом юстиції, обласною прокуратурою, обласною організацією товариства «Знання» підготовлено документ «Адміністративна і кримінальна відповідальність за порушення законодавства про релігійні культи» (методичні рекомендації для допомоги ідеологічному активу, комісіям сприяння виконання законодавства про релігійні культи і адміністративним комісіям виконкомів рад народних депутатів, працівникам органів міліції, суду і прокуратури) [9, арк. 196].

Завдяки обласній комісіі, керівництво обкому Компартії України і облвиконкому було ознайомлено 3 постановою Ради у справах релігій при Раді Міністрів УРСР від 19 травня 1980 р. «Про стан і заходи посилення роботи щодо виявлення і протидії противозаконній діяльності секти Свідків Сгови». На прохання Уповноваженого Ради у справах релігій в Івано-Франківській області це питання 1 серпня 1980 року обговорювалася на обласному засіданні ідеологічних працівників райкомів, міськкомів КПРС, керівних працівників органів внутрішніх справ і прокуратури області. На початку жовтня 1980 р. до партійних і радянських органів влади були направлені пропозищії щодо посилення роботи щодо виявлення і припинення діяльності єговістів, а також покращення всіх форм виховної профрілактичної роботи з віруючими. 3 цією ж метою до виконкомаів місцевих рад був направлений план відповідних заходів, розроблений місцевим Уповноваженим Ради у справах релігій. Подібні плани щодо покращення роботи з єговістами були складені райміськвиконкомами і сільськими радами області [9, арк. 198].

Провівши перевірку діяльності місцевих комісій 3 приймання виконання законодавство про релігійні культи, Рада у справах релігій при Раді Міністрів УРСР констатувала, що у них наявні розгорнуті плани роботи, чітко розподілені обов'язки між членами комісії. Здебільшого комісії мали списки всіх нелегальних протестантських громад 3 «демографічними характеристиками», діти свідків Сгови, п'ятидесятників були взяті на спеціальний контроль. 3 а ними, відповідно до звітних документів, велася постійна профрілактична робота. Члени комісії час від часу виїжджали до місця проживання протестантів 3 метою детального роз'яснення законодавства про релігійні культи [9, арк. 200].

Відзначимо, що перші три виїзні бригади для роботи із протестантським спільнотами були створені в Івано-Франківській області у 1976 р. До їх складу увійшли працівники прокуратури, студенти-атеїсти, викладачі вузів, учителі середніх шкіл. На думку Уповноваженого Ради у справах релігій при Раді Міністрів УРСР в Івано-Франківської області, завдяки вжитим заходам більшість Свідків Сгови, п'ятидесятників хоча й неохоче, але все ж таки брали участь у виборчих кампаніях, a їх діти були задіяні в громадському житті. Однак доводиться констатувати, що заходи обласної комісії не 
приносили бажаних результатів для обкому Компартії України. Позитивні тенденщії щодо зменшення чисельності протестантських громад були помітні у 1968-1973 роках: у цей період кількість Свідків Єгови зменшилася із 2500 до 1496 осіб. Однак надалі помітно яскрава тенденщія до збільшення кількості віруючих Свідків Сгови. Зокрема у 1973 нараховувалося 1631 особа, 1974 рощі 1743, 1975 році - 1812, 1976 році-1859. У 1981 році в Івано-Франківській області місцевими радянсько-партійними органами влади було зафіксовано 1843 свідки Сгови [9, арк. 200].

Важливе значення обласна комісія надавала роботі 3 п'ятидесятниками Івано-Франківської області. У 1978 р. зусиллями обкому компартії України та обласної комісії вдалося зареєструвати одну релігійну громаду цієї спільноти (село Слобода Калушського району). 16 релігійних громад п'ятидесятників відмовляються від реєстрації та проводили «антирадянську діяльність». На відміну від свідків Єгови, кількість яких упродовж 1977-1981 рр. практично не змінилася, чисельність п'ятидесятників за цей же період зросла із 784 осіб до 900. Особливе занепокоєння партчиновників викликав фракт наявності у представників цієї релігійної громади стійких еміграційних настроїв. П'ятидесятники нерідко відмовляються від служби у лавах Збройних Сил СРСР (у 1978-1981 рр. від строкової військової служби відмовилися 7 призовників-п'ятидесятників) [9, арк. 201].

Для пропаганди атеїзму державно-партійні органи влади Івано-Франківщини проводили спеціальні тематичні вечори у селах, де проживали проуніатськи настоєні віруючі в Тлумацькому, Долинському районах Івано-Франківської області. У селах Церковна, Станьковці, Бубнище, Танява Долинського району були проведені спеціальні кінолекторії, де демонструвалися фрільми «Троянський кінь», «Вампіри», «Останні сторінки» та ін. "До недавнього часу, уніати періодично використовували недіючі культові споруди в селах Тарновиця Івано-Франківського та Гостів Тлумацького районів», - відзначали партчиновники [8, арк. 24].

Серед заходів Ради у справах релігій при Раді Міністрів УРСР «Щодо подальшого покращення роботи щодо впорядкування мережі релігійних організацій, освоєнню культових споруд, контролю за дотриманням і застосуванням законодавства про релігійні культи» можна виокремити:

1. Провести республіканську нараду уповноважених у справах релігій з питань удосконалення роботи щодо контролю за дотриманням законодавства про релігійні культи» (грудень 1983 р.).
2. Провести звірку даних релігійних організацій, які не перебувають на обліку (грудень 1983 р. - січень 1984 р.).

3. Надати практичну допомогу уповноваженим ради у справах релігій щодо здійснення контролю за перебігом освоєння культових споруд у Волинській, Закарпатській, Тернопільській, Львівській, Київській, Одеській та чернівецькій областях (1984-1985 рр.).

4. Надати практичну допомогу місцевим радам, на території яких продовжують діяти незареєстровані релігійні громади уніатів (перше півріччя 1984 р.).

5. Виробити практичні рекомендації щодо припинення діяльності домашніх монастирів (1984р.).

6. Виробити практичні рекомендащії щодо контролю над дотриманням законодавства про релігійні культи (листопад-грудень 1983 р.) [10, арк. 1].

У «Статистичному звіті Ради за 1982 р.» відзначено, що у звітному році відбулося 1464 обласних, районних семінарів 3 питань атеїзму, проведено 16325 розмов з віруючими і духовенством, 1403 виступі в пресі, радіо і телебаченні. Виявлено 2759 порушень законодавства про культи, в результаті чого 3720 осіб притягнуто до адміністративної відповідальності. У 61 населеному пункті західноукраїнських областей віруючі продовжували самочинно відкривати храми і «влаштовувати в них збори». В Івано-Франківській, Тернопільській, Івано-Франківській областях допускався «формальний підхід до розгляду листів і заяв віруючих громадян» [10, арк. 1].

Висновки 3 даного дослідження і перспективи. У 1970-х - першій половині 1980-х рр. державно-партійні органи влади доклали чимало зусиль для пропаганди атеїстичного світогляду в УРСР. В Івано-Франківській області партчиновники зіткнулися із значними проблемами в окресленій cфpepi, зважаючи на високу релігійність населення. Для пропаганди атеїзму державно-партійні органи влади Івано-Франківщини проводили спеціальні тематичні вечори у селах, де проживали проуніатськи настоєні віруючі, організовували спеціальні кінолекторії, де демонструвалися фільми «Троянський кінь», «Вампіри», «Останні сторінки» та ін. Важливу роль в атеїстичній пропаганді було відведено обласній Комісії сприяння виконання законодавства про культи, створеній з ініціативи Уповноваженого Ради у справах релігій при раді Міністрів СРСР. Перспективний напрям подальших досліджень - аналіз атеїстичної кампанії державно-партійних органів влади у Львівській та Тернопільській областях у період розвинутого соціалізму.

\section{Список літератури:}

1. ДАІФО. Ф. Р-388. Оп. 1. Спр. 31. 250 арк.

2. Бажан О., Данилюк В. Випробування вірою: боротьба за реалізацію прав і свобод віруючих в Україні в другій половині 1950-1980-х рр. Київ, 2000. 329 с.

3. Бондарчук П. Релігійна свідомість віруючих УРСР (1940-1980-і роки): повсякденні прояви, трансформації. Київ, 2012. $321 \mathrm{c}$.

4. Войналович В. Партійно-державна політика щодо релігії та релігійних інституцій в Україні 1940-1960-х років: політологічний дискурс. Київ, 2005. 741 с.

5. Марчук В. Церква, духовність, нація. Українська греко-католицька церква в суспільному житті України ХХ ст. Івано-Франківськ, 2004. 464 с.

6. Пащенко В. Греко-католики в Україні. Від 40-х pp. ХХ ст. до наших днів. Полтава, 2002. 616 с.

7. ДАІФО. Ф. Р-338. Оп. 2. Спр. 95. 287 арк. 
8. ДАІФО. Ф. Р-388. Оп. 1. Спр. 39. 145 арк.

9. ЦДАВО України. Ф. 4648. Оп. 8. Спр. 207. 202 арк.

10. ДАІФО. Ф. Р-338. Оп. 1. Спр. 48. 178 арк.

\section{References:}

1. DAIFO. F. R-388. Op. 1. Spr. 31. 250 ark.

2. Bazhan O., Danyljuk V. (2000) Vyprobuvannja viroju: borotjba za realizaciju prav i svobod virujuchykh v Ukrajini v drughij polovyni 1950-1980-kh rr. [The Test of Faith: The Struggle for the Realization of the Rights and Freedoms of Believers in Ukraine in the Second Half of the 1950s and 1980s]. Kyiv. (in Ukrainian)

3. Bondarchuk P. (2012) Relighijna svidomistj virujuchykh URSR (1940-1980-i roky): povsjakdenni projavy, transformaciji [Religious consciousness of believers of the USSR (1940-1980s): everyday manifestations, transformations]. Kyiv. (in Ukrainian)

4. Vojnalovych V. (2005) Partijno-derzhavna polityka shhodo relighiji ta relighijnykh instytucij v Ukrajini 1940-1960-kh rokiv: politologhichnyj dyskurs [Party-State Policy on Religion and Religious Institutions in Ukraine in the 1940s and 1960s: Political Science Discourse]. Kyiv. (in Ukrainian)

5. Marchuk V. (2004) Cerkva, dukhovnistj, nacija. Ukrajinsjka ghreko-katolycjka cerkva v suspiljnomu zhytti Ukrajiny XX st. [Church, spirituality, nation. Ukrainian Greek Catholic Church in the public life of Ukraine in the twentieth century]. Ivano-Frankivsjk. (in Ukrainian)

6. Pashhenko V. (2002) Ghreko-katolyky v Ukrajini. Vid 40-kh rr. XX st. do nashykh dniv [Greek Catholics in Ukraine. From the 40's of the twentieth century to this day]. Poltava. (in Ukrainian)

7. DAIFO. F. R-338. Op. 2. Spr. 95. 287 ark.

8. DAIFO. F. R-388. Op. 1. Spr. 39. 145 ark.

9. TsDAVO Ukrainy. F. 4648. Op. 8. Spr. 207. 202 ark.

10. DAIFO. F. R-338. Op. 1. Spr. 48. 178 ark. 